\title{
An easily overlooked cause of acute kidney injury: Questions
}

\author{
Sare Gülfem Özlü ${ }^{1}$ (D) $\cdot$ Zehra Aydin $^{2} \cdot$ Aylin Kilinç Uğurlu ${ }^{2} \cdot$ Mehmet Boyraz $^{3} \cdot$ Umut Selda Bayrakçi $^{1}$
}

Received: 18 October 2020 / Accepted: 20 November 2020 / Published online: 7 January 2021

(C) IPNA 2021

Keywords Adolescent $\cdot$ Constipation $\cdot$ Amenorrhea $\cdot$ Edema

\section{Question}

A 17-year-old girl was admitted because of progressive fatigue, weakness, and involuntary weight gain (6 kg in the last 4 months). She complained of long-lasting constipation. She had amenorrhea for the last 3 months and loin pain for 2 weeks. She had been diagnosed with congenital hypothyroidism since 1 month of age, but she had not adhered to her medications for the last couple of months. She was a nonsmoker and did not consume alcohol. She did not complain of any change in urine color, smell, or output. Except for parental consanguinity, her family history was unremarkable.

On physical examination, she had pale and dry skin, her weight was $66 \mathrm{~kg}$ (75-90 percentile), height was $160 \mathrm{~cm}$ (2550 percentile), and BMI was $25.8 \mathrm{~kg} / \mathrm{m}^{2}$. Blood pressure was $100 / 60 \mathrm{mmhg}$, heart rate $78 / \mathrm{min}$. Pretibial $2+$ non-pitting edema was detected. The thyroid gland was diffusely and symmetrically enlarged. She also had tenderness on bilateral costovertebreal angle. She did not have hepatosplenomegaly or lymphadenopathy; neurological and cardiological examinations and other systemic examinations were all normal.

The answers to these questions can be found at https://oi.org/10.1007/ s00467-020-04882-z1

Sare Gülfem Özlü

saredr@gmail.com

1 Ankara Yildirim Beyazit University Faculty of Medicine, Department Of Pediatric Nephrology, Ankara City Hospital, Ankara, Turkey

2 Department Of Pediatric Endocrinology, Ankara City Hospital, Ankara, Turkey

3 Department of Pediatric Endocrinology, Ankara Yıldırım Beyazıt University, Faculty of Medicine, Ankara, Turkey
Laboratory investigations revealed normal urine analysis without proteinuria, hematuria, or pyuria. Urine culture was sterile, and acute phase reactants were not elevated. She had mild anemia on complete blood count with hemoglobin level $10.5 \mathrm{~g} / \mathrm{dL}$ and mean corpuscular volume $90 \mathrm{fL}$. Blood urea nitrogen was $24 \mathrm{mg} / \mathrm{dL}$, creatinine $1.15 \mathrm{mg} / \mathrm{dL}$ (estimated GFR $59 \mathrm{ml} / \mathrm{dk} / 1.73 \mathrm{~m}^{2}$ ), uric acid $3.9 \mathrm{mg} / \mathrm{dL}$, albumin 4.8 $\mathrm{g} / \mathrm{dL}$, sodium $139 \mathrm{mEq} / \mathrm{L}$, potassium $4.9 \mathrm{mEq} / \mathrm{L}$, and phosphorus $4.7 \mathrm{mg} / \mathrm{dL}$. Arterial blood gas was normal. Liver enzymes were in normal limits. Total cholesterol was $143 \mathrm{mg} / \mathrm{dL}$ and triglycerides level was $75 \mathrm{mg} / \mathrm{dL}$. Serum-free thyroxine $\left(\mathrm{FT}_{4}\right)$ was $0.26 \mathrm{ng} / \mathrm{dL}(0.83-1.43)$, free triiodothyronine $\left(\mathrm{FT}_{3}\right)$ was $1.39 \mathrm{ng} / \mathrm{mL}(3-4.7)$, and thyroid-stimulating hormone was $145.72 \mathrm{mU} / \mathrm{L}(0.51-4.94)$. Kidney and bladder ultrasound was normal. Thyroid ultrasound revealed slightly enlarged thyroid gland with fibrous bands on parenchymal tissue.

\section{Questions}

1. What is the best description of the clinical picture of this patient?

2. Which additional tests would you perform to identify the underlying pathophysiology?

3. How should this patient be managed?

\section{Compliance with ethical standards}

Conflict of interest The authors declare that they have no conflict of interest.

Publisher's note Springer Nature remains neutral with regard to jurisdictional claims in published maps and institutional affiliations. 